Research Article

\title{
Design of Low-Cost and Simple Reconstruction Method for Three Dimensional Electrical Impedance Tomography (3D-EIT) Imaging
}

\author{
Endarko ${ }^{1, a, *}$ and Ari Bangkit Sanjaya Umbu ${ }^{1, b}$ \\ ${ }^{1}$ Department of Physics, Faculty of Science and Data Analytics, Institut Teknologi Sepuluh Nopember (ITS) \\ Kampus ITS, Sukolilo, Surabaya 60111, Indonesia \\ e-mail: ${ }^{\mathrm{a}}$ endarko@physics.its.ac.id and ${ }^{\mathrm{b}}$ aribangkit.sanjaya@gmail.com \\ * Corresponding Author
}

\begin{abstract}
Electrical impedance tomography is a non-invasive imaging modality that uses the electrical conductivity distribution to reconstruct images based on potential measurements from the object's surface. The proposed study was to design and fabricate a low-cost and simple reconstruction method for $3 D$ electrical impedance tomography imaging. In this study, we have been successfully developed 3 Dimensional Electrical Impedance Tomography (3D-EIT) system using 16 copper electrodes $(\mathrm{Cu})$ to detect and reconstruct the presence of objects in the Phantom. 3D-EIT was developed using Phantom as a test object with PVC pipe material, with an inner diameter of $7.2 \mathrm{~cm}$ and a height of $5.4 \mathrm{~cm}$. Electrodes were arranged in two rings, with each ring having eight electrodes arranged in a planar line. Furthermore, the Gauss-Newton algorithm and Laplace prior regularization were used to image reconstruction of objects inside the Phantom using voltage measurement produced from sequential pairs of neighboring electrodes. The voltage is obtained from the injection of a constant current of $1 \mathrm{~mA}$ at $20 \mathrm{kHz}$ into the system's electrode pairs. The objects used in this research are PVC pipe, solid aluminum, PVC pipes filled with wax glue, and copper trusses. The results obtained show that the reconstruction results can provide information about the position, the electrical properties, and the shape of real objects. Finally, the system can detect the location, height, and electrical properties of objects for all variations of angle and height variations.
\end{abstract}

Keywords: Phantom; Imaging; Impedance; Tomography; $3 D$

\section{Desain Metoda Rekonstruksi dengan Biaya Rendah dan Sederhana untuk Pencitraan Tomografi Impedansi Listrik Tiga Dimensi}

\begin{abstract}
Abstrak
Electrical Impedance Tomography adalah modalitas pencitraan non-invasif yang menggunakan distribusi konduktivitas listrik untuk merekonstruksi gambar berdasarkan pengukuran potensial dari permukaan objek. Studi yang diusulkan adalah untuk merancang dan membuat metode rekonstruksi berbiaya rendah dan sederhana untuk tiga dimensi Electrical Impedance Tomography. Pada penelitian ini telah berhasil dikembangkan sistem 3 Dimensional Electrical Impedance Tomography (3D-EIT) dengan menggunakan 16 elektroda tembaga (Cu) untuk mendeteksi dan merekonstruksi keberadaan objek pada Phantom. 3D-EIT dikembangkan menggunakan Phantom sebagai benda uji dengan material
\end{abstract}

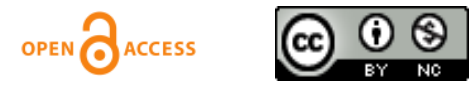


pipa PVC dengan diameter dalam 7,2 $\mathrm{cm}$ dan tinggi 5,4 cm. Elektroda disusun dalam dua cincin, dengan masing-masing cincin memiliki delapan elektroda yang disusun dalam garis planar. Selanjutnya, algoritma Gauss-Newton dan Laplace prior regularization digunakan untuk rekonstruksi gambar objek di dalam Phantom menggunakan pengukuran tegangan yang dihasilkan dari pasangan sekuensial elektroda tetangga. Tegangan tersebut diperoleh dari injeksi arus konstan $1 \mathrm{~mA}$ pada $20 \mathrm{kHz}$ ke dalam sistem pasangan elektroda. Objek yang digunakan dalam penelitian ini adalah pipa PVC, aluminium padat, pipa PVC yang diisi lilin, dan tembaga. Hasil yang diperoleh menunjukkan bahwa hasil rekonstruksi dapat memberikan informasi tentang posisi, sifat listrik, dan bentuk benda nyata. Terakhir, sistem dapat mendeteksi lokasi, ketinggian, dan sifat listrik objek untuk semua variasi sudut dan variasi ketinggian.

Kata Kunci: Phantom; Pencitraan; Impedansi; Tomografi;3D

PACS: 87.63.Pn; 07.05.Hd; 07.07.Df; 87.63.-d; 4.37.+q

(C) 2020 Jurnal Penelitian Fisika dan Aplikasinya (JPFA). This work is licensed under CC BY-NC 4.0

Article History: Received: May 20, 2020

Accepted: December 3, 2020
Aproved with minor revision: December 23, 2020

Published: December 31, 2020

How to cite: Endarko and Umbu ABS. Design of Low-Cost and Simple Reconstruction Method for Three Dimensional Electrical Impedance Tomography (3D-FET) Imaging. Jurnal Penelitian Fisika dan Aplikasinya (JPFA). 2020; 10(2): 125-136. DOI: https://doi.org/10.26740/jpfa.v10n2.p125-136.

\section{INTRODUCTION}

Electrical Impedance Tomography (EIT) is an imaging technique and radiation-free that uses electrical signals to reconstruct an image from the human body's conductivity distribution information. EIT is a promising technique that has been used in various fields such as industry, geophysics, and medical application [1-8]. This imaging technique is an imaging technique that has advantages compared to other imaging techniques. The superiority of the EIT imaging technique is relatively inexpensive to make, simple, portable, and does not cause ionizing radiation to the body [9]. In its application, the EIT device for the medical world was first developed by Barber and Brown in the early 1980s and has been utilized for monitoring gastric emptying, lung function, heart function, nerve function, water quantity in the lungs lung, and detecting breast cancer [10].

In principle, EIT estimates electrical conductivity distribution on an object when an electric current is applied to the object's surface. The voltage on the pair of electrodes that have been set on the object's surface will be measured or vice versa $[11,12]$. The measurement data obtained are then used for the reconstruction process of the object's observed conductivity distribution. The measurement is based on the object's electrical nature (material) [11-15].

Imaging techniques with EIT rely heavily on the instrumentation device's ability or hardware to produce accurate data and reconstruction algorithms in the reconstruction process [16-18]. There are still various improvements and developments, to both hardware and software, in a reconstruction algorithm to obtain maximum results $[19,20]$. The design and fabrication of two or three-dimensional electrical impedance tomography are well established. However, there is very little information available in the literature regarding the capability to use the Neighboring method of two-dimensional electrical impedance tomography to produce a three-dimensional image. 
Aligning with the research mentioned above, in this study, we proposed hardware and software for three-dimensional electrical impedance tomography with a low cost and simple reconstruction method. We used the Neighboring Method, which is usually applied to the two-dimensional EIT (2D-EIT) system, to reconstruct the 3D-EIT system image. The effect of variations in the angle of placement of objects, the height of objects, distance of placement of objects from the Phantom center, and variations in the conductivity of objects in Phantom on reconstructing the image generated on the 3D-EIT system will also be investigated.

\section{METHOD}

In general, the EIT system consists of six major parts, namely the Voltage-controlled current source (VCCS) block, the multiplexer- demultiplexer block, the voltage measuring block, the control unit, the Phantom container, and the computing-display unit. An illustration of the configuration of the EIT system for reconstruction is shown in Figure 1.

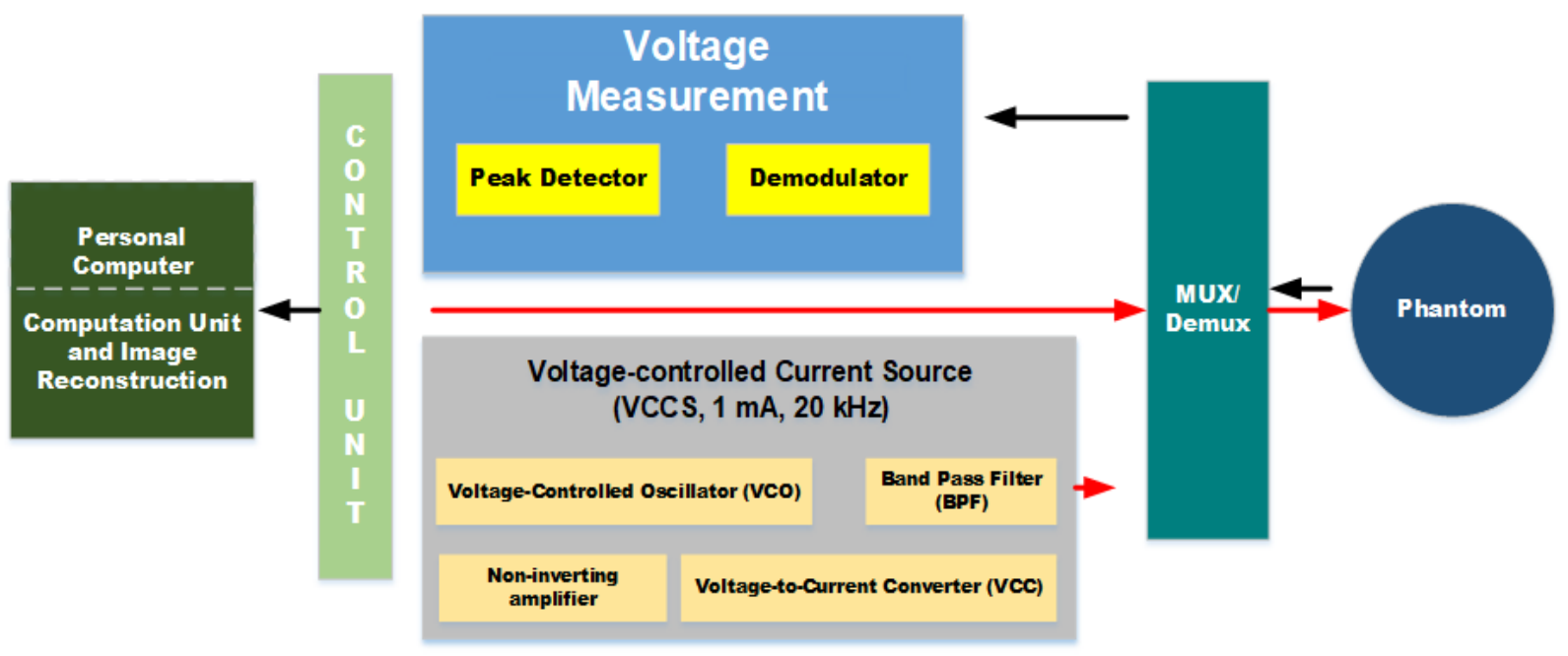

Figure 1. Block Diagram for the Prototype of a 3D-EIT System that Uses for Image Reconstruction

Voltage-controlled current source (VCCS) circuit blocks function designed to produce a current of $1 \mathrm{~mA}$ and $20 \mathrm{kHz}$ frequency that will be injected into the object to observe its conductivity distribution, as shown in Figure 1. The choice of a frequency of $20 \mathrm{kHz}$ refers to signal penetration when applied to live tissue in medical applications. The $20 \mathrm{kHz}$ frequency is insusceptible to beta dispersion $(10 \mathrm{kHz}-10 \mathrm{MHz})[21]$.

The demultiplexer and multiplexer circuit functions are designed to regulate the flow injection current from the VCCS circuit block to the electrodes. The potential difference measurement pathway leads to the voltage measurement circuit block. This circuit consists of four eight-channel relay modules and two HC4067 ICs.

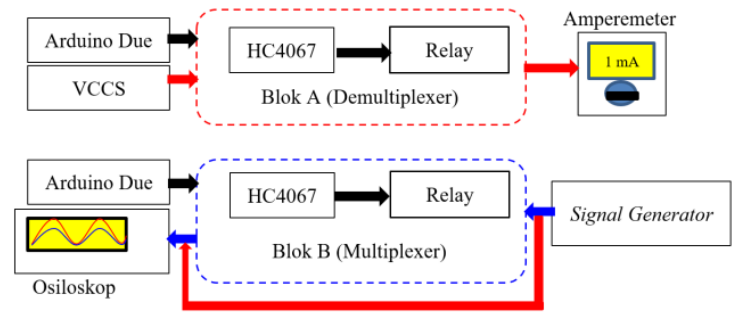

Figure 2. Block Diagram for Demultiplexers and Multiplexers

The Phantom was made from PVC pipes with an inner diameter of $7.2 \mathrm{~cm}$ and a height of $5.4 \mathrm{~cm}$. Furthermore, we used copper $(\mathrm{Cu})$ with a length of $1 \mathrm{~cm}$, a width of $1 \mathrm{~cm}$, and a thickness of $0.4 \mathrm{~mm}$ for the 
electrodes surrounding the Phantom. The design of the Phantom cylinder container and the placement of copper $(\mathrm{Cu})$ electrodes for the fabricated 3D-EIT are shown in Figure 3.

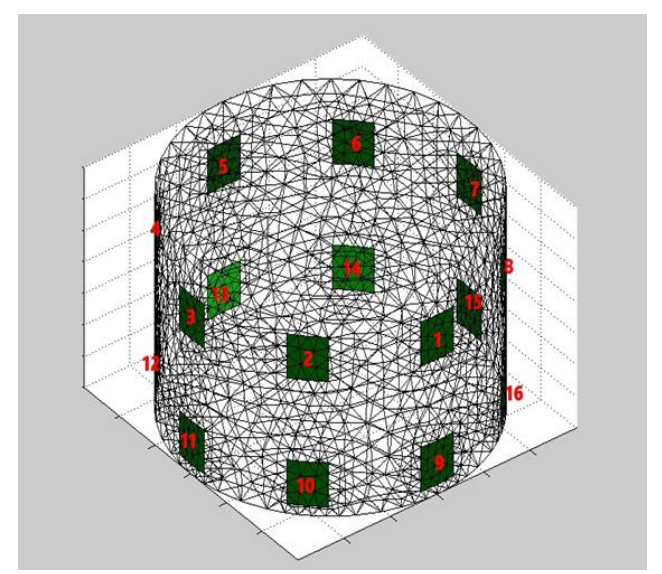

Figure 3. The Placement of Copper Electrode Plates (Cu) in the Wall of Phantom

The 3D Phantom design consists of 2 rings with eight copper $(\mathrm{Cu})$ electrodes for each ring that use a combination of electrodes arranged in a lined and planar electrode configuration. The arrangement of the electrode placement configuration is based on the results obtained by Graham and Adler. These results indicate that the Aligned-Planar configuration provides a reconstructed result with a sharp contrast in the center and less noise [22].

The voltage measuring circuit block function was used for recording a potential difference that appears on the electrode when the Phantom is injected with the current. In this circuit, a block consists of two series, namely the demodulator circuit and the peak detector circuit, as shown in Figure 1.

The control unit in the 3D-EIT uses Arduino Due with a 12 bit ADC resolution. Arduino Due is used to control the current injection process, the voltage measurement channel on the Phantom and serves as a liaison for the EIT circuit with a personal computer [23]. The Arduino Due is chosen as a control unit due to its ADC resolution precision to produce more accurate measurements.

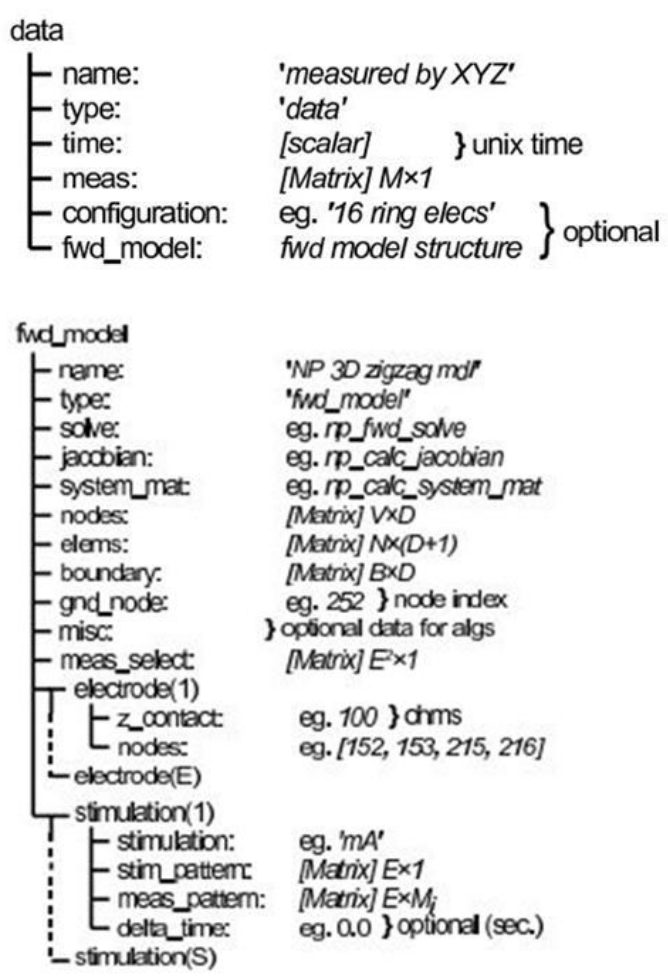

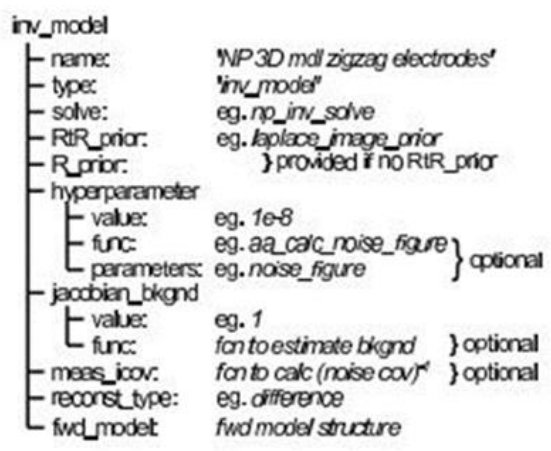

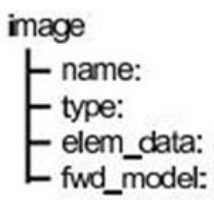

'3D simulation'

'image' [Matrix] $N \times 1$ fud model structure

Figure 4. Algorithm Structure in EIDOR [24,25] 
In software design, Arduino Software 1.5.8 (IDE), Matlab R2014a, and EIDORS 3.8 are used. Arduino Software (IDE) is used to create programs used by the control unit (Arduino Due) to regulate current injection, voltage measurement, and voltage reading. Meanwhile, Matlab and EIDORS [24,25] are used as data processing and computing units.

The EIDORS software working in the Matlab application basically consists of four main objects: data, image, fwd_model (forward model), and inv_model (inverse model) (see Figure 4). The four main objects have elements consisting of a name and type. The element names of these four objects can be given arbitrarily, and the type elements of the four main objects are used to identify the types of objects such as data and images.

The current injection and measurement method of electrical potential refers to the Neighboring Method applied in the 2D-EIT case. The injection current is applied to electrodes 1 and 2 (see Figure 3), then the measurement of electrical potential is carried out on the other electrode pairs. The procedure will continue to repeat and shift until all pairs of electrodes have been injected with the current. The amount of data obtained in one data frame is 208 data. In the study, the Gauss-Newton algorithm and Laplace prior regularization were used in image reconstruction. This algorithm was chosen because it can produce a smooth image on the side plane, thus making the conductivity value distribution of material appears real, which will produce a good image in terms of shape, size, and position of the object on the Phantom. The Equations 1 and 2 are used in the Gauss-Newton algorithm $[1,6]$.

$$
\begin{aligned}
& \hat{x}=\left\|z-J_{x}\right\|^{2}+\left\|x-x_{0}\right\|^{2} \\
& B=\left(J^{T} W J+\lambda^{2} R\right)^{-1} J^{T} W
\end{aligned}
$$

where $\hat{x}$ is a minimum value of the quadratic normalization, $z$ is the voltage changes, $x_{0}$ the expectation value of conductivity changes, $x$ is the conductivity value change, $J$ is the
Jacobian matrix, $J^{T}$ is the transpose of Jacobian matrix, $\lambda$ is hyperparameter value, $W$ is the weight of matrix, $R$ is regularization matrix Jacobian Matrix, and $B$ is Gauss-Newton linear one-step reconstruction matrix.

Meanwhile, to get the smoother results of image reconstruction, we use vertex density in the finite element method (FEM) models with FEM models "i2c2" on the EIDORS system [25].

\section{RESULTS AND DISCUSSION}

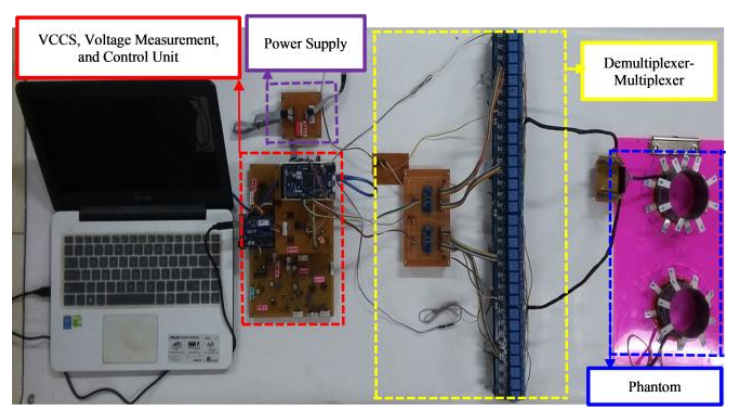

(a)

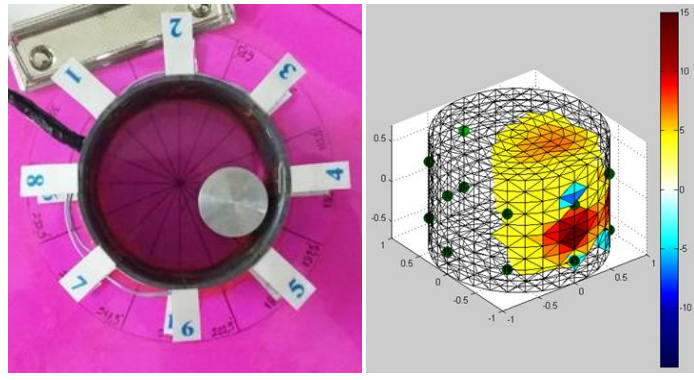

(b)

Figure 5. The Fabricated 3D-EIT System: (a)

Hardware of 3D-EIT and (b) Sample of the

Reconstructed 3D Image

In general, research has successfully demonstrated the low-cost and simple reconstruction method for Three Dimensional Electrical Impedance Tomography (3D-EIT) Imaging as shown in Figure 5. The developed system can read objects with variations in the distance of the placement of objects to the Phantom's center, varies in the angle of placement of objects, and height of objects in the Phantom, although it actually still has limitations in constructing images of the object being analyzed. 
3D-EIT Testing with Variation of Object Placement Angle in Phantom

In this study, three objects with different conductivity are used: solid aluminum, copper coils, and PVC pipes. This test has proposed to determine the sensitivity of the fabricated EIT system for variations in the conductivity of impurity objects with various angles of the position in the Phantom (see Figure 6) and the ability to reconstruct in 3-dimensional images.

Figure 7 shows the reconstructed image in the EIT system testing with variations in the angle of placement of objects in the Phantom.

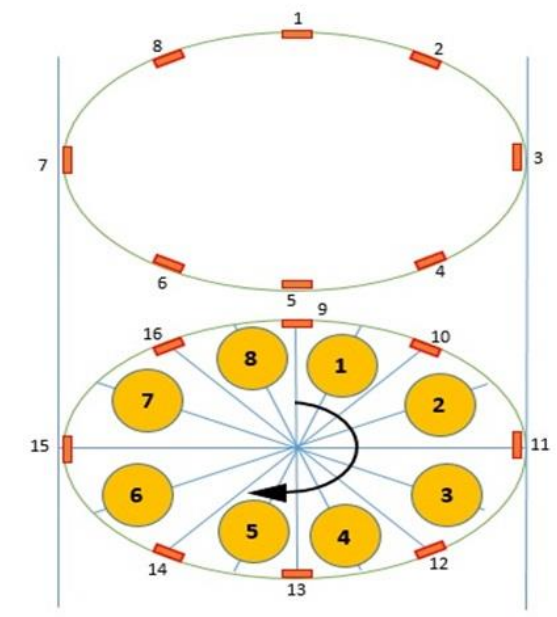

Figure 6. Scheme of Objects with Variations in the Angle of Electrode Placement, Namely: (1) $22.5^{\circ}$, (2) $67.5^{\circ}$, (3) $112.5^{\circ}$, (4) $157.5^{\circ}$, (5) $202.5^{\circ}$, (6) $247.5^{\circ}$, (7) $292.5^{\circ}$, and (8) $337.5^{\circ}$

It can be seen from Figure 7 that the system has been able to provide good reconstruction results in terms of consistency in detecting the electrical properties of objects at each test angle and accuracy in identifying the angle in which the impurity object is located. However, the system still has limitations in showing good reconstruction results regarding the consistency of the form of reconstruction at each test angle and consistency in displaying color contrast at each test angle for one impurity object.

This is probably due to the little number of electrodes used so that it causes the limitation in reading of the distribution of electrical potential in the Phantom [26]. To overcome this problem, increasing the number of electrodes should be done, as Sarode has reported that the EIT system's performance could be improved by increasing the number of electrodes [13]. Henderson and Webster also support this fact; they used 100 electrodes formed into a rectangular arrangement to reconstruct the human tissues' impedance [27].

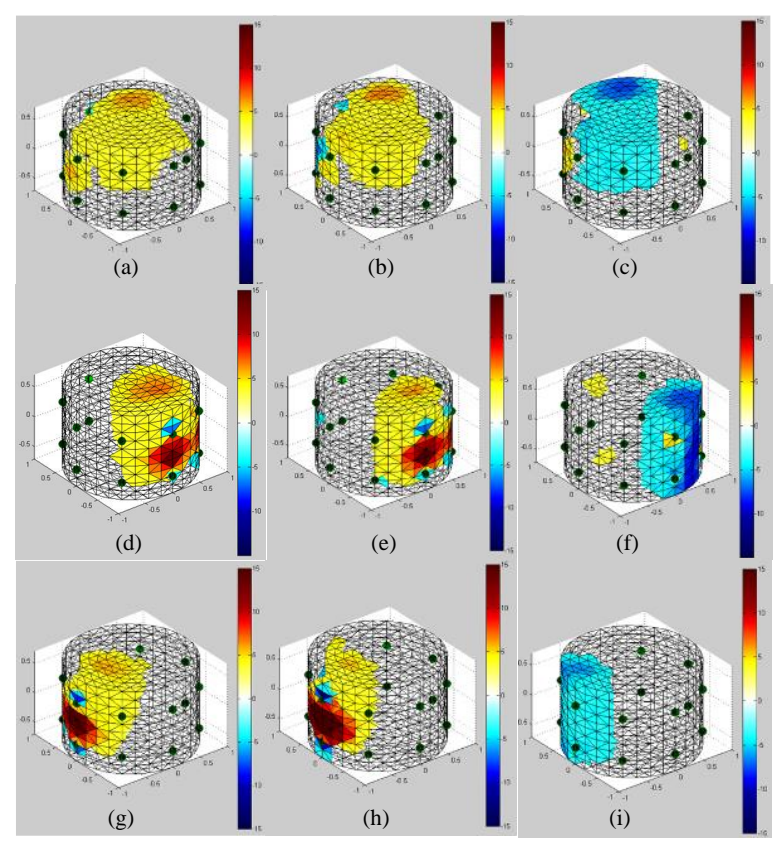

Figure 7. The Reconstructed Image of Object

Placement in Phantom with Variations in the Angle of Object Placement: (a) Aluminum (22.5 ${ }^{\circ}$ ),

(b) Copper Coils (22.5 ${ }^{\circ}$ ), (c) PVC Pipes (22.5 ${ }^{\circ}$,,

(d) Aluminum (157.5 ${ }^{\circ}$, e) Copper Coils (157.5 ${ }^{\circ}$ ),

(f) PVC Pipes (157.5 ${ }^{\circ}$, g) Aluminum (292.5 ${ }^{\circ}$ ),

(h) Copper Coils $\left(292.5^{\circ}\right)$, and (i) PVC Pipe

$\left(292.5^{\circ}\right)$

3D-EIT Testing with Variations in the Distance of Impurity Objects to the Phantom Center

In this session, the study aimed to determine the system's sensitivity when an object that acts as an impurity is placed in a distance from the electrode, acting as a current transmitter and acting as a sensor to read potential differences. The object is 
placed between the Phantom and the electrode's central point and electrode 5 and 13 (see Figure 8).

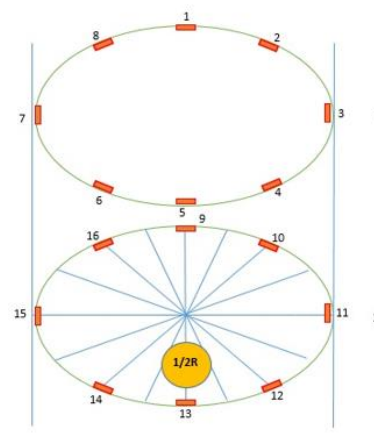

(a)

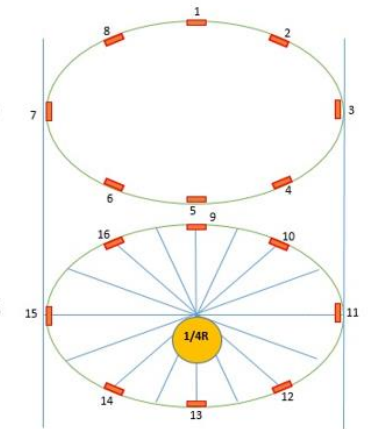

(b)

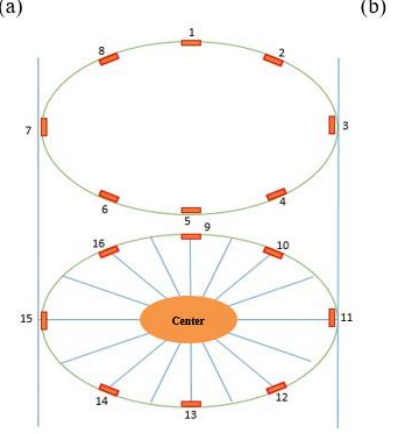

(c)

Figure 8. Scheme of Objects with Variations in

Distance to the Center of Phantom (a) Radius = 1/2 R, (b) Radius = 1/4 R, and (c) Radius $=0$

The objects used in this test are solid aluminum, copper coils, and PVC pipes. The distance variations used are $1 / 2$ Phantom radius, 1/4 Phantom radius, and Phantom center point with $\mathrm{R}=0$ as a reference, as shown in Figure 9. Figure 9 also shows the reconstructed image that resulted in this study.

It can be analyzed from Figure 9 that the position of the object that is getting closer to the center of the Phantom shows the results of its reconstruction getting closer to the actual shape of the object when compared to the other two distances. When observing 3D-EIT image reconstruction results with variations in the center of this Phantom gives different results in 2D-EIT image reconstruction, which uses the same injection method and voltage measurement. In the case of $2 \mathrm{D}$-EIT, using the Neighboring method tends to produce a weak contrast when the impurity object is placed in the middle of the Phantom $[1,2]$. This fact shows that using the Neighboring method adopted from 2D-EIT to reconstruct images in 3D-EIT is quite effective and successful. The difference in results is not solely due to the use of the Neighboring Method. The designed system has been combined with electrodes arranged in rows and an Electrode Placement (EP) with a planar configuration. It is consistent with what was revealed by Graham and Adler [28], Wagenaar and Adler [29], Maimaitijiang [30], and Alder [31] in their research in comparing several combinations and configurations of electrode placement using 16 electrodes in the case of 3D-EIT, which will provide excellent and reliable reconstruction results in the middle of the Phantom and is best at minimizing noise.

\section{EIT Testing with Impurity Object Height Variations}

In the test, we used two objects that function as impurities: copper coils and PVC pipes made robust by filling the pipe's cavity with wax glue. Applying the height variations could also be used to observe in the EIT system's performance and to detect objects with different conductivity (variations in the conductivity of impurity objects). The test used two variations of impurity objects, such as those previously described. The height of the objects used in testing was at 1, 1.5, 2.4, $3.8,4.3$, and $5.3 \mathrm{~cm}$, respectively. The testing scheme in this section is shown in Figure 10.

The 3-dimensional image reconstruction of the impurity object for the object in the form of a copper coil $(\mathrm{Cu})$ at the height variation of the impurity object is shown in Figure 11. Meanwhile, the 3-dimensional image reconstruction for the object's impurity object's actual position in the form of a PVC pipe that filled the cavity with 
wax glue for the height variations is shown in Figure 12.

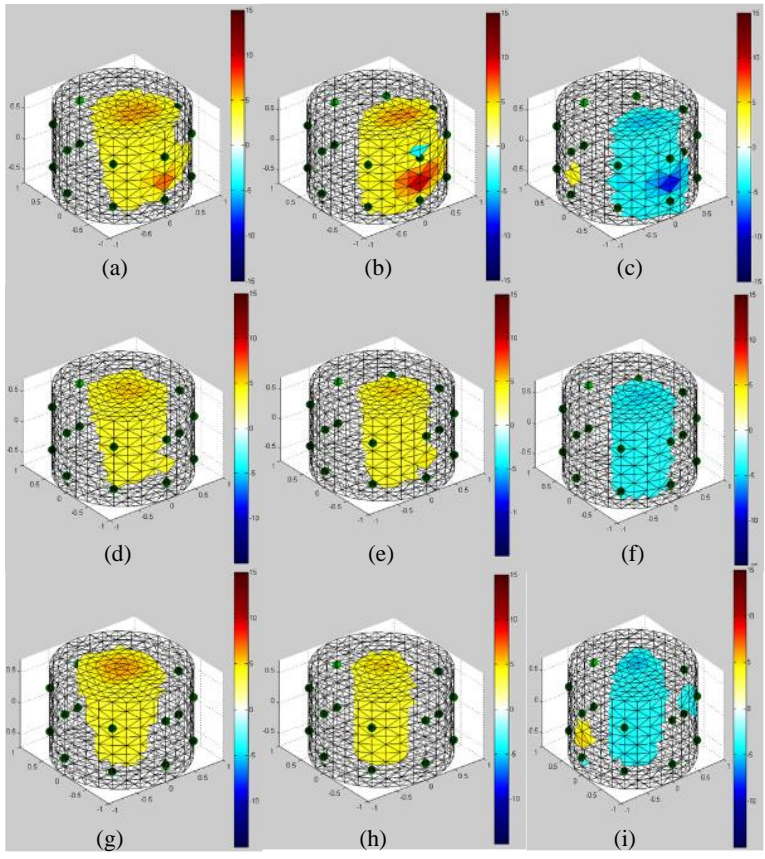

Figure 9. The Reconstructed Image in the Variation in the Distance of the Location of the Impurity

Object to the Center of the Phantom: a) Solid

Aluminum at 1/2 R, b) Copper Coils at 1/2 R, c)

PVC Pipe at 1/2 R, d) Solid Aluminum at 1/4 R, e)

Copper Coils at Distance 1/4 R, f) PVC Pipe at a

Distance of 1/4 R, g) Solid Aluminum at the Center of the Phantom $(R=0), h)$ Copper Coils at the

Center of the Phantom $(R=0)$, and i) PVC Pipe at the Center of the Phantom $(R=0)$

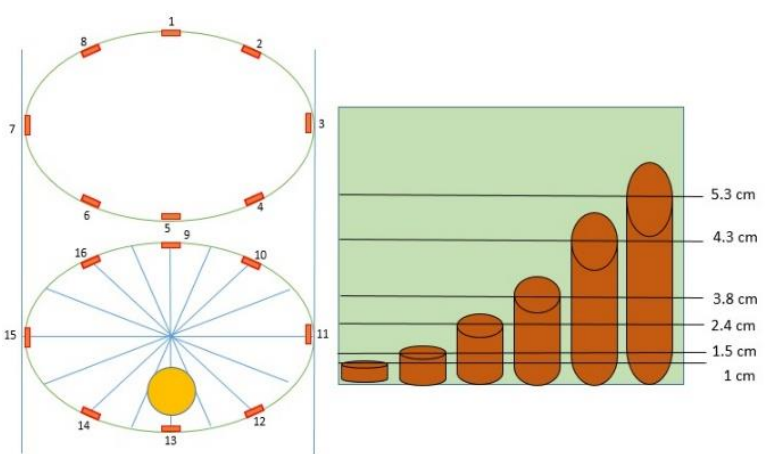

Figure 10. Scheme of Objects with Variations in

\section{Height}

Figure 11 shows the system could detect the impurity object's presence with variations in the object's height from copper coils. Still, for objects with a height smaller than the height of the Phantom, the system has not been able to provide image reconstruction results that are close to the actual shape of the object. This fact, due to the system only uses 16 electrodes divided into two rings so that the Phantom's potential distribution density that reads electrodes becomes wider and rougher.

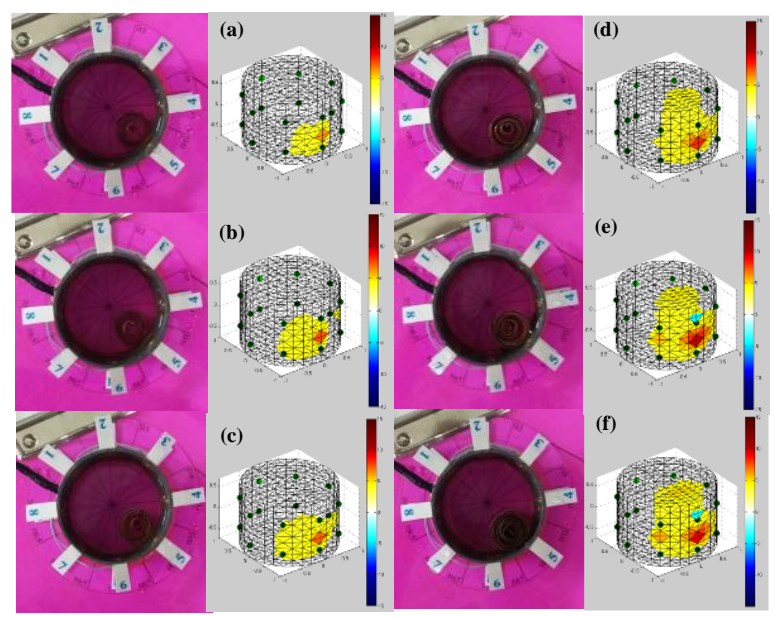

Figure 11. The Position of the Actual Object and Image Reconstruction with Varies the Height of

Form of Copper Coils: a) $1 \mathrm{~cm}$, b) $1.5 \mathrm{~cm}$, c) $2.4 \mathrm{~cm}$, d) $3.8 \mathrm{~cm}$, e) $4.3 \mathrm{~cm}$, and f) $5.3 \mathrm{~cm}$

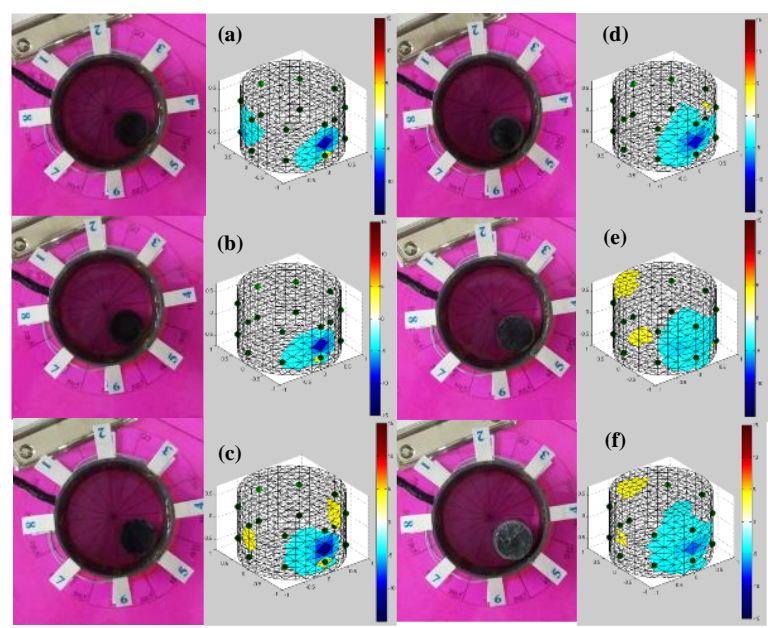

Figure 12. The Position of the Actual Object and Image Reconstruction with Varies at the Height of PVC Pipes: a) $1 \mathrm{~cm}$, b) $1.5 \mathrm{~cm}$, c) $2.4 \mathrm{~cm}$, d) $3.8 \mathrm{~cm}$, e) $4.3 \mathrm{~cm}$, and f) $5.3 \mathrm{~cm}$

Furthermore, the impurity object used in the variation of object height is a solid PVC pipe, as shown in Figure 12. Similar to the results obtained in testing using copper coils, the reconstruction results obtained using solid 
PVC pipe objects as impurities in the Phantom also provide excellent results in predicting the location and electrical properties of objects placed in Phantom. However, the system still unable to provide reconstruction results close to the objects' actual shape for objects with a small height.

Overall, testing with variations in the height of the impurity object (impurity) using two objects with different electrical properties provides good reconstruction results in predicting the location and electrical properties of the Phantom's impurity object.

This system's inability to provide the results of 3-dimensional image reconstruction approaching the shape of the actual impurity object in objects with a small height is caused by the system being built only composed of 16 electrodes. Each ring only consists of 8 electrodes. It causes a decrease in the system's sensitivity in reading changes in the distribution of potential differences read by electrodes on the Phantom. This problem can be overcome by increasing the number of rings and the number of electrodes in the 3D-EIT system [32]. It follows what was expressed by Sarode, who stated that the EIT system's performance could be improved by increasing the number of electrodes [13].

In general, the present study has successfully demonstrated the design and fabrication with a simple reconstruction method for Three Dimensional Electrical Impedance Tomography (3D-EIT) imaging. This research is expected to impact further research in the medical physics field, especially in developing a diagnostic system with ionizing radiation-free modalities.

\section{CONCLUSION}

The present study has demonstrated the use of the Neighbor method adopted from the 2D-EIT system with aligned and planar electrodes arranged in the 3D-EIT case seems to be very influential in improving image reconstruction throughout the Phantom region. This method is proven to produce an excellent image reconstruction in the middle of Phantom and great in minimizing noise. Based on visual inspection on the distribution of potential inside the Phantom, it is shown that the 3D-EIT system has succeeded in producing image reconstruction with variations in the object's placement angle, the distance of the object's placement to the Phantom center, the height of the object, and the electrical properties of the object. In general, the system that has been fabricated has the opportunity to be developed further in medical imaging applications.

\section{REFERENCES}

[1] Farha $\mathrm{M}$ and Endarko. Combined Algorithm of Total Variation and Gauss-Newton for Image Reconstruction in Two-Dimensional Electrical Impedance Tomography (EIT). Proceedings of 2017 International Seminar on Sensor, Instrumentation, Measurement and Metrology: Innovation for the Advancement and Competitiveness of the Nation, ISSIMM 2017. Universitas Airlangga, Surabaya. 2017; 37-41. DOI: http://dx.doi.org/10.1109/ISSIMM.2017.812 4257.

[2] Aris W and Endarko. Design of Low-Cost and High-Speed Portable Two-Dimensional Electrical Impedance Tomography (EIT). International Journal of Engineering and Technology. 2019; 7(4): 6458-6463. Available from:

https://www.sciencepubco.com/index.php/ije t/article/view/23298.

[3] Umbu ABS and Endarko. The Design of Voltage Controlled Current Source (VCCS) for Single Frequency Electrical Impedance Tomography (EIT). Proceedings of 2017 International Seminar on Sensor, Instrumentation, Measurement and Metrology: Innovation for the Advancement and Competitiveness of the Nation, ISSIMM 
Jurnal Penelitian Fisika dan Aplikasinya (JPFA), 2020; 10(2): 125-136

2017. Universitas Airlangga, Surabaya. 2017; 30-36. DOI:

https://doi.org/10.1109/ISSIMM.2017.81242 $\underline{56 .}$

[4] Puspitasari AJ and Endarko. Study of Precision Constant Current Sources with Resistor Load and a Cole-Cole Load for Multi-Frequency in Electrical Impedance Tomography. Proceeding of 2016 International Seminar on Sensors, Instrumentation, Measurement and Metrology, ISSIMM 2016. Universitas Brawijaya, Malang. 2016; 12-17. DOI: http://dx.doi.org/10.1109/ISSIMM.2016.780 3713.

[5] Gong B, Krueger-Ziolek S, and Moeller K. An Efficient Classification-Reconstruction Method for 3D-EIT Imaging. IFAC-PapersOnLine. 2018; 51(27): 36-40. DOI:

http://dx.doi.org/10.1016/j.ifacol.2018.11.60 $\underline{4}$.

[6] Hikmah I, Rubiyanto A, and Endarko. Two-Dimensional Electrical Impedance Tomography (EIT) for Characterization of Body Tissue Using a Gauss-Newton Algorithm. Journal of Physics: Conference Series. 2019; 1248: 012008. DOI: http://dx.doi.org/10.1088/1742-6596/1248/1/ 012008.

[7] Goren N, Avery J, Dowrick T, Mackle E, Witkowska-Wrobel A, Werring D, and Holder D. Data Descriptor: Multi-Frequency Electrical Impedance Tomography and Neuroimaging Data in Stroke Patients. Scientific Data. 2018; 5: 180112. DOI: http://dx.doi.org/10.1038/sdata.2018.112.

[8] Putensen C, Hentze B, Muenster S, and Muders T. Electrical Impedance Tomography for Cardio-Pulmonary Monitoring. Journal of Clinical Medicine. 2019; $\quad$ 8(8): $1176 . \quad$ DOI: http://dx.doi.org/10.3390/jcm8081176.

[9] Singh G, Anand S, Lall B, Srivastava A, and Singh V. Development of a Microcontroller
Based Electrical Impedance Tomography System. 2015 IEEE Long Island Systems, Applications, and Technology. Farmingdale, New York. 2015; 1-4. DOI:

https://doi.org/10.1109/LISAT.2015.7160174.

[10] Teschener E, Imhoff M, and Leonhardt S. Electrical Impedance Tomography: The Realisation of Regional Ventilation Monitoring, 2nd Edition. Lübeck: Dräger Medical GmbH; 2015.

[11] Trigo FC, Gonzalez-Lima R, and Amato MBP. Electrical Impedance Tomography Using the Extended Kalman Filter. IEEE Transactions on Biomedical Engineering. 2004; 51(1): 72-81. DOI: http://dx.doi.org/10.1109/TBME.2003.8203 89.

[12] Adler A, Dai T, and Lionheart WRB. Temporal Image Reconstruction in Electrical Impedance Tomography. Physiological Measurement. 2007; 28(7): S1. DOI: https://doi.org/10.1088/0967-3334/28/7/S01.

[13] Sarode V, Chirmurkar PM, and Cheeran AN. Electrical Impedance Tomography Using EIDORS in a Closed Phantom. International Journal of Computer Applications. 2012; 48(19): 48-52. DOI: http://dx.doi.org/10.5120/7460-0526.

[14] Zhou Y and Li X. A Real-Time EIT Imaging System Based on the Split Augmented Lagrangian Shrinkage Algorithm. Measurement. 2017; 110: 27-42. DOI: http://dx.doi.org/10.1016/j.measurement.201 7.06.018.

[15] Zhou Z, Li N, Xu H, Guo J, Sun Z, Liu H, and $\mathrm{Yu} \mathrm{H}$. The Design and Implementation of a Portable EIT Telemedicine System. Proceedings of 2012 International Conference on Intelligent Systems Design and Engineering Applications, ISDEA 2012. Hainan. 2012; 571-575. DOI:

http://dx.doi.org/10.1109/ISdea.2012.741.

[16] Chen B and Soleimani M. Depth Analysis of Planar Array for 3D Electrical Impedance Tomography. IEEE Sensors Journal. 2019; 
Jurnal Penelitian Fisika dan Aplikasinya (JPFA), 2020; 10(2): 125-136

19(22): 10710-10718. DOI:

http://dx.doi.org/10.1109/JSEN.2019.29296

$\underline{25}$.

[17] Besler E, Wang YC, Chan TC and Sahakian AV. Real-Time Monitoring Radiofrequency Ablation Using Tree-Based Ensemble Learning Models. International Journal of Hyperthermia. 2019; 36(1): 427-436. DOI: http://dx.doi.org/10.1080/02656736.2019.15 $\underline{87008 .}$.

[18] Hrabuska R, Prauzek M, Venclikova M, and Konecny J. Image Reconstruction for Electrical Impedance Tomography: Experimental Comparison of Radial Basis Neural Network and Gauss - Newton Method. IFAC-PapersOnLine. 2018; 51(6): 438-443. DOI:

http://dx.doi.org/10.1016/j.ifacol.2018.07.11 $\underline{4}$.

[19] Khalighi M, Vahdat, BV, Mortazavi M, Hy W, and Soleimani M. Practical Design of Low-Cost Instrumentation for Industrial Electrical Impedance Tomography (EIT). 2012 IEEE International Instrumentation and Measurement Technology Conference Proceedings. Graz, Austria. 2012; 1259-1263. DOI:

http://dx.doi.org/10.1109/I2MTC.2012.6229 173.

[20] Luo Y, Abiri P, Zhang S, Chang C-C, Kaboodrangi AH, Li R, Sahib AK, Bui A, Kumar R, Woo M, Li Z, Packard RRS, Tai Y-C, and Hsiai TK. Non-Invasive Electrical Impedance Tomography for Multi-Scale Detection of Liver Fat Content. Theranostics. 2018; 8(6): 1636-1647. DOI:

http://dx.doi.org/10.7150/thno.22233.

[21] Chitturi V and Farrukh N. Development Of An Agilent Voltage Source For Electrical Impedance Tomography Applications. ARPN Journal of Engineering and Applied Sciences. 2016; 11(5): 3270-3275. Available from:

http://www.arpnjournals.org/jeas/research p apers/rp 2016/jeas 0316 3795.pdf.
[22] Graham BM. Enhancements in Electrical Impedance Tomography (EIT) Image Reconstruction for $3 D$ Lung Imaging, University of Ottawa. PhD Thesis. Canada: University of Ottawa; 2007. DOI: http://dx.doi.org/10.20381/ruor-12954.

[23] Arduino - ArduinoDue. Getting Started with the Arduino Due. Available from: https://www.arduino.cc/en/Guide/ArduinoD ue [accessed 17 July 2017].

[24] Adler A and Lionheart WRB. Uses and Abuses of EIDORS: An Extensible Software Base for EIT. Physiological Measurement. 2006; 27(5): S25-S42. DOI: http://dx.doi.org/10.1088/0967-3334/27/5/S0 3.

[25] EIDORS. Electrical Impedance Tomography and Diffuse Optical Tomography Reconstruction Software. Available from: http://eidors3d.sourceforge.net/ [accessed 17 July 2017].

[26] Yin X, Wu H, Jia J, and Yang Y. A Micro EIT Sensor for Real-Time and Non-Destructive 3-D Cultivated Cell Imaging. IEEE Sensors Journal. 2018; 18(13): 5402-5412. DOI: http://dx.doi.org/10.1109/JSEN.2018.28345 $\underline{09}$.

[27] Khan TA and Ling SH. Review on Electrical Impedance Tomography: Artificial Intelligence Methods and Its Applications. Algorithms. 2019; 12(5): $88 . \quad$ DOI: http://dx.doi.org/10.3390/a12050088.

[28] Graham BM and Adler A. Electrode Placement Configurations for 3D-EIT. Physiological Measurement. 2007; 28(7): S29. DOI:

http://dx.doi.org/10.1088/0967-3334/28/7/S0 3 .

[29] Wagenaar $\mathbf{J}$ and Adler A. Electrical Impedance Tomography in 3D Using Two Electrode Planes: Characterization and Evaluation. Physiological Measurement. 2016; 37(6): 922-937. DOI: 
Jurnal Penelitian Fisika dan Aplikasinya (JPFA), 2020; 10(2): 125-136

http://dx.doi.org/10.1088/0967-3334/37/6/92 $\underline{2}$.

[30] Maimaitijiang Y, Gürsoy D, and Adler A. Electrode Positions and Current Patterns for 3D-EIT; Proceeding of Conference on Biomedical Applications of Electrical Impedance Tomography. University of Bath, UK. 2011. Available from: https://www.researchgate.net/publication/26 7220949 Electrode positions and current patterns for 3D EIT.

[31] Adler A, Gaggero PO, and Maimaitijiang Y. Adjacent Stimulation and Measurement
Patterns Considered Harmful. Physiological Measurement. 2011; 32(7): 731-744. DOI: http://dx.doi.org/10.1088/0967-3334/32/7/S0 1.

[32] Cherepenin V, Karpov A, Korjenevsky A, Kornienko V, Mazaletskaya A, Mazourov D, and Meister D. A 3D Electrical Impedance Tomography (EIT) System for Breast Cancer Detection. Physiological Measurement. 2001; 22(1) : 9-18. DOI:

http://dx.doi.org/10.1088/0967-3334/22/1/30 2. 